\title{
Microplankton assemblages in three Rías Baixas (Vigo, Arosa and Muros, Spain) with a subsurface chlorophyll maximum: their relationships to hydrography
}

\author{
Francisco G. Figueiras, Yolanda Pazos \\ Instituto de Investigaciones Marinas, Eduardo Cabello 6, CSIC, E-36208 Vigo, Spain
}

\begin{abstract}
During summer 1984, when coastal upwelling had diminished, a subsurface chlorophyll maximum (SCM) was found in 3 Galician rias which are characterized by strong thermal stratification and a nutricline at 10 to $30 \mathrm{~m}$ depth. The SCM formed directly above the nutricline and was composed mainly of diatoms, although the dinoflagellates Ceratium horridum and Ceratium fusus and the ciliate Mesodinium rubrum were also present. The contribution of $M$. rubrum was especially important in the center of the Ría de Muros. It was possible to recognize 3 phytoplankton assemblages by means of principal component analysis. Assemblage 1, composed of heterotrophic dinoflagellates and ciliates, was found above the SCM, indicating a possible vertical segregation in the feeding mode when an SCM is formed in the rías. Assemblage 2, consisting of flat dinoflagellates (Dinophysis spp.), elongated diatoms (Nitzschia delicatissima, Rhizosolenia alata giacillina, Nitzschia seriata-like) and the dinoflagellates C. horridum and C. fusus, was present in more oceanic stations, suggesting some kind of interchange between rías and ocean. A third assemblage (diatoms) showed a marked neritic distribution, and was found below the SCM in waters with higher nutrient concentrations. Similarly, canonical correlation analysis showed that all the phytoplankton were characteristic for a post-bloom period, when important trophic relationships began establishing themselves in the system. However, Assemblage 1 was more heterotrophic in character than Assemblage 2. Within this general background there were differences among rías related to hydrography. In Arosa, with a hydrographic structure suggesting more mixing than in the other 2 rías, a cluster composed of diatoms was more abundant and frequent. Muros, with the strongest fluvial input, occupied an intermediate position between Arosa and Vigo.
\end{abstract}

\section{INTRODUCTION}

Studies carried out in the 1950s on the annual cycle of phytoplankton in the Ría de Vigo (Margalef et al. 1955, Durán et al. 1956) partly contributed to establishing the foundations of the classical theory of phytoplanktonic succession in temperate waters (Margalef 1958, 1978). Later studies (Figueiras \& Niell 1987b) related this succession to coastal upwelling, concluding that with the first upwelling events of the year large diatom species develop, and that between successive upwelling pulses a subsurface chlorophyll maximum (SCM) is established, formed by both small and elongated diatoms, with which diverse dinoflagellates, oligotrichous ciliates and small flagellates coexist. At the end of the season favourable to upwelling (October), when stratification is very strong and the surface layers are depleted of nutrients, it is usual for potential red-tide formers to appear, many of which are capable of vertical migration (Figueiras \& Fraga 1990, Figueiras \& Pazos 1991).

Until now the majority of the phytoplankton studies carried out in the Rias Baixas were devoted to temporal variability (e.g. Margalef et al. 1955, Figueiras \& Niell $1987 \mathrm{a}, \mathrm{b})$, focusing principally on temporal phytoplankton succession and red-tide formation. Only a few works have dealt with spatial heterogeneity by comparing different rías (Varela et al. 1987a, b).

Seasonal coastal upwelling in this area, typically more pronounced from March to October (Wooster et al. 1976), is intermittent in intensity. For this reason, when the upwelling diminishes, the nutrient-rich water layers do not reach the photic layer but can often be found at a depth of 50 to $60 \mathrm{~m}$, deep enough to enter 
the rías by positive estuarine circulation (e.g. Fraga \& Margalef 1979, Blanton et al. 1984, Figueiras et al. 19851.

Due to the positive estuarine circulation and the shallowness of the rias in their innermost parts, a weak upwelling on the coast is sufficient to produce a response of the phytoplankton populations inside the rias (Figueiras \& Niell 1986, 1987a, b). Because of this, the rias are considered exporters of biomass towards the coast (Estrada 1984).

In this context it seems particularly important to study the summer phytoplankton, in order to understand in greater detail the assemblages which occur during formation of the SCM, when the microplankton fraction appears to be more trophically complex. It is especially important to compare different rías, very close to each other but with distinct hydrographic regimes, and to discover how these regimes influence the phytoplankton assemblages. Thus, this study considers the phytoplankton found in 3 Galician rías (Vigo, Arosa and Muros\}, and their relationship to hydrography during a period of weak upwelling, when an SCM was present.

\section{MATERIAL AND METHODS}

During the Galicia VIII cruise of the RV 'Garcia del Cid', carried out on the Galician coast in July and August 1984, samples were taken at 25 stations in the Vigo, Arosa and Muros rías (Fig. 1). Niskin bottles (1.7 1) equipped with reversible thermometers were used. Sample depths were $0,5,10,20,30,40,50,60,80$ and $100 \mathrm{~m}$, whenever water depth permitted. For phytoplankton counts, samples were only taken down to $20 \mathrm{~m}$, except at 2 stations in the Ria de Vigo (Stns 103 and 104), where samples were taken to $30 \mathrm{~m}$ depth. The Ria de Vigo was sampled on 30 July, Arosa on 1 August and Muros on 3 August.

Salinity was determined using a Beckman RS-9 induction salinometer, and calculated using Eq. (6) of UNESCO (1981). The pH was determined using a glass electrode with another electrode of $\mathrm{Ag}$ - $\mathrm{AgCl}$ (as reference) calibrated with buffer 7.413 NBS (National Bureau of Standards); at the same time, temperature was measured with a precision of $\pm 0.1 \mathrm{C}^{\circ}$, which allowed us to calculate all the corresponding $\mathrm{pH}$ values at $15^{\circ} \mathrm{C}$ (Pérez \& Fraga 1987). Oxygen was analysed using the Winkler method.

All nutrients were measured on board immediately after sampling with an autoanalyzer. Nitrates were determined by reduction to nitrites in a $\mathrm{Cd}$-Cu column according to the modification of Mouriño \& Fraga (1985). Nitrites, phosphates and silicates were analysed following the method given by Hansen \& Grasshoff

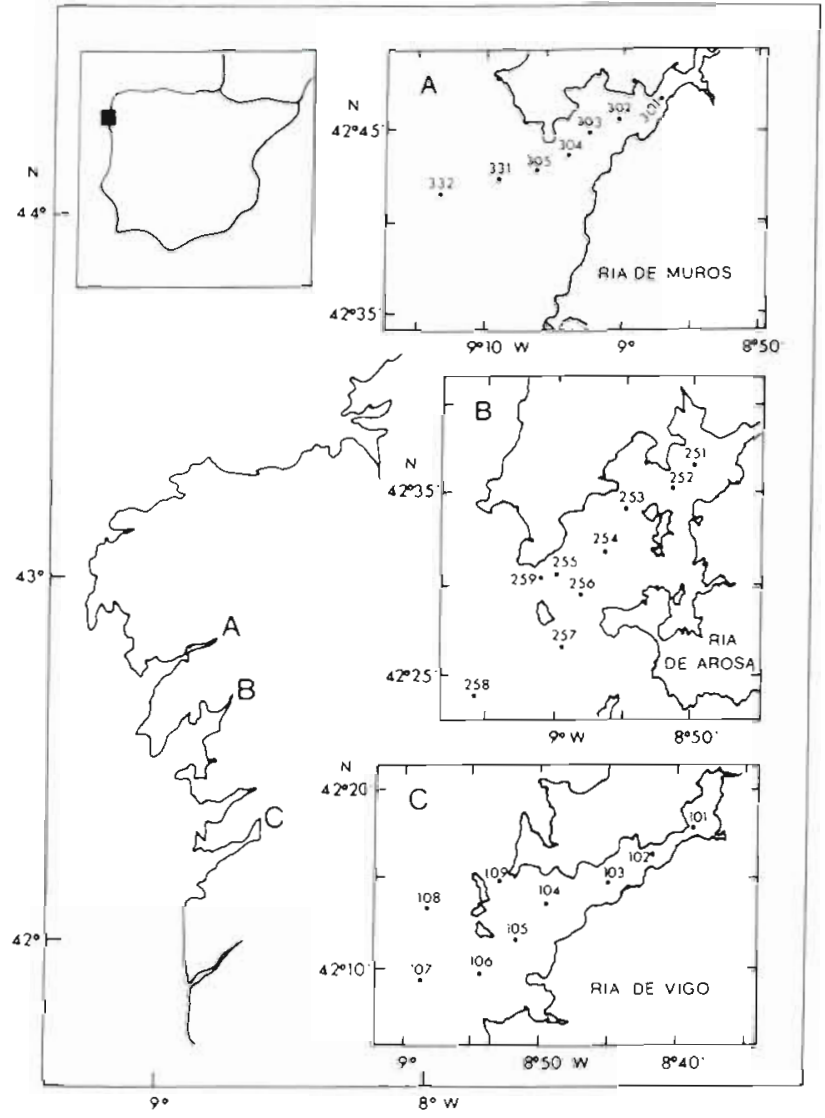

Fig. 1. Rías de Vigo, Arosa and Muros, Spain, showing station locations

(1983). Chlorophyll a was determined by fluorometry (Yentsch \& Menzel 1963, Strickland \& Parsons 1972).

The internal Rossby radius of deformation was used to estimate the strength of fluvial contribution in each ría:

$$
r_{3}=N h / f
$$

where $N=$ Brunt-Väisälä frequency; $h=$ thickness of the water layer; $f=$ the Coriolis parameter. $N$ was approximated by

$$
N^{2}=g\left(\rho_{z}+\Delta z-\rho_{z}\right) / \Delta_{z}
$$

where $g=$ gravity, $\rho=$ seawater density and $z=$ depth. These calculations were made only at the station closest to the riverine, in a water column of $10 \mathrm{~m}$ depth.

Counts and identifications of organisms were made with an inverted microscope, using sedimentation chambers containing Lugol-fixed samples. Together with organisms traditionally considered as phytoplankton, oligotrichous and peritrichous ciliates were also counted. This was justified, since many of these ciliates contain chloroplasts (e.g. Taylor 1982, Stoecker et al. 1987, 1989, Laval-Peuto \& Rassoulzadegan 1988, Crawford 1989), and because their function within the ecosystem is not very different from that attributed to 
the dinoflagellates (e.g. Packard et al. 1978, LavalPeuto et al. 1986, Stoecker et al. 1988). The organisms were classified to the species level when possible. Nevertheless, many of them, especially the small forms and the ciliates, were combined into large taxonomic groups. In any case, for these small forms as for the majority of naked dinoflagellates, the specific name must be understood more as an indication of morphological structure than as an accurate identification.

Two kinds of analyses [principal component (PCA) and cluster analyses] were performed to define the phytoplankton assemblages. From the data matrix resulting from organism counts (including the ciliates), species or groups of species present in at least $50 \%$ of the samples were combined into another matrix (41 species $\times 92$ samples), starting from which the analysis of principal components was made. A correlation matrix was employed using log-transformed data $[\log (x+1)$, where $x=$ the number of cells per $50 \mathrm{ml}]$. Elimination of the rare species is necessary so that the correlation matrix does not contain double zeros (Legendre \& Legendre 1983). Using the same correlation matrix a cluster analysis of the variables was made, using the average linkage method to form the clusters. When all the species forming an identified cluster were present in a sample, the cluster value in this sample was considered to be the average of the species abundances (Legendre \& Legendre 1983). In order to find the most objective relations possible between the physico-chemical environment and the phytoplankton assemblages, a canonical correlation analysis (CCA) was performed on the untransformed physico-chemical data and the phytoplankton components extracted by PCA. The predictive result that CCA analysis can yield was not considered, since the temporal variation in an upwelling system invalidates any generalisation of the coefficients obtained based on only a few observations.

\section{RESULTS}

\section{The physico-chemical environment}

Geomorphological characteristics, as well as data on fluvial discharge during sampling, are presented in Table 1 for the 3 rías. Vigo is the longest of the 3 and Arosa the widest. Average fluvial discharges for the 7 days preceding the observations were very low and not at all variable in Vigo; Arosa and Muros received similar inputs, although in Muros they were much more variable. This is due to the fact that the river which flows into the Muros ría (the Tambre) is regulated by a reservoir, so that average inputs to the ría in the $3 \mathrm{~d}$ prior to sampling were $35.9 \pm 3.93 \mathrm{~m}^{3} \mathrm{~s}^{-1}$. Consequently, water-column stratification at the stations
Table 1. Morphological characteristics and river transport during sampling in the Rías de Vigo, Arosa and Muros, Spain. River discharge is the average (SD) for the $7 \mathrm{~d}$ before sampling. $N$ is the Brunt-Väisälä frequency in the innermost station of each ria; $r_{1}$ is the internal Rossby radius calculated for the water layer at $10 \mathrm{~m}$ depth in these stations

\begin{tabular}{|llcc|}
\hline & Vigo & Arosa & Muros \\
\hline Length $(\mathrm{km})$ & 33 & 25 & 18 \\
Mean width $(\mathrm{km})$ & 5.3 & 9.2 & 6.9 \\
Width length & 0.16 & 0.37 & 0.38 \\
River discharge & $2.88(0)$ & $22.7(1.2)$ & $22.2(14.3)$ \\
$\quad\left(\mathrm{m}^{3} \mathrm{~s}^{-1}\right)$ & & & \\
$N\left(\mathrm{~s}^{-1}\right)$ & 0.02 & 0.04 & 0.06 \\
$r_{i}(\mathrm{~km})$ & 2.28 & 4.50 & 6.81 \\
\hline
\end{tabular}

nearest the river mouths (reflected by the Brunt-Väisälä frequency) was greater in the Muros ría. This greater fluvial input could also be seen in the internal Rossby radius.

The hydrography of the 3 rías (Figs. 2 to 4) was characterized by a distinct thermal stratification. This stratification was greater in the Ría de Vigo, where there was a gradient of $5 \mathrm{C}^{\circ}$ between the surface and $10 \mathrm{~m}$ depth at the inner stations. The gradient was more pronounced close to the riverine end; the temperature range was similar in all 3 rias $\left(12\right.$ to $\left.18^{\circ} \mathrm{C}\right)$, with a slightly greater surface temperature at Stns 102 and 103 of the Ría de Vigo.

Pattern of salinity distribution were in general, similar to those for temperature; in this respect, the Ría de Arosa, on the whole, was less densely stratified than Vigo and Muros. Nevertheless, in the 2 stations of Arosa closest to the riverine end (Stns 251 and 252), fluvial imput was appreciable. This fluvial contribution, evidenced by the reduction in salinity at the surface of the innermost stations, was more important in Muros (31.4\%o) than in Arosa (34.7\%n) and Vigo (35.0\%). In the bottom samples salinity was the same for the 3 rías.

Nitrate distributions indicated a surface layer (varying between 10 and $30 \mathrm{~m}$ depending on the ría) depleted of nutrients. In the profiles for Vigo and Arosa a shallowing of the nitrate isolines could be seen at the outermost stations (Stns 106 and 257), which was also perceptible for temperature and salinity. Close to both stations the bottom topography steepened, and a weak thermal and haline front also existed. On the other hand, in the Ría de Muros, where the change in water depth is more gradual, a doming in these isolines was not found, but rather a deepening of surface water at Stn 305, which depressed the nitrate isolines. Next to this depression some weak domings were observed

Taking into account the vertical resolution obtainable with the discrete sampling used in this study, 

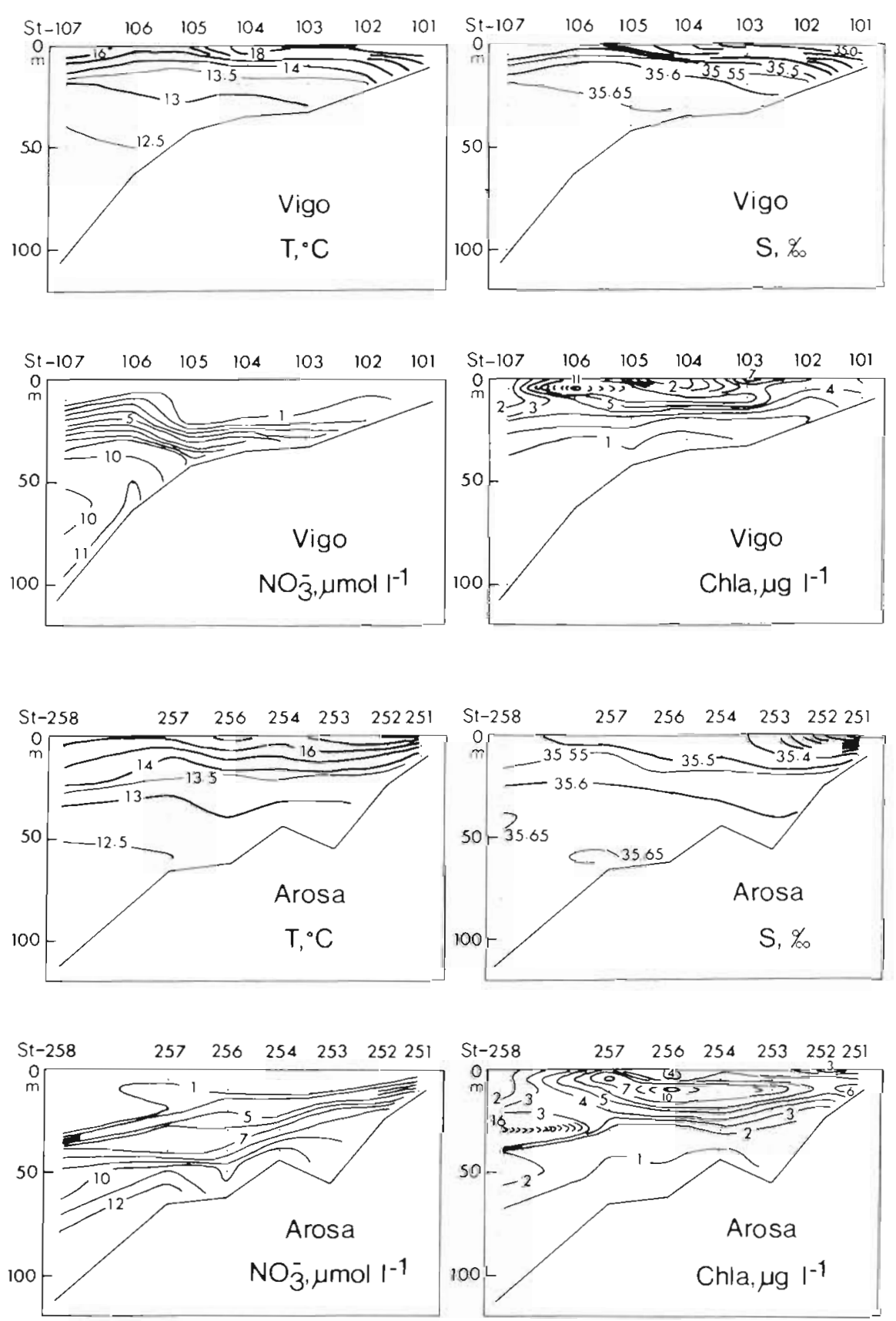

Fig. 2. Distributions of temperature, salinity, nitrates and chlorophyll $a$ in Ría de Vigo chlorophyll distributions indicated (1) the existence of a subsurface maximum just above the nitrate gradient, and (2) the presence of an oceanic limit beyond which the subsurface chlorophyll concentration diminished in Vigo and Muros and which separated an SCM from a deeper chlorophyll maximum in Arosa. This chlorophyll front was located between Stns 257 and 258 in Arosa (with the deeper chlorophyll maximum located at $\operatorname{Stn} 258$, outside of the estuary itself), at Stns 332 and 331 in Muros, and at Stns 106 and 107 in Vigo.

\section{Phytoplankton}

The phytoplankton standing stock and distributions of the main groups (diatoms, dinoflagellates and other groups) are shown in Figs. 5 to 7 . Total cell numbers coincided fairly closely with chlorophyll concentrations (see Figs. 2 to 4), but with some discrepancy in the interior zones, where chlorophyll maxima did not exactly correspond with cell maxima. Diatoms were the most abundant group in the phytoplankton maxima, reaching percent- 
Fig. 4. Distributions of temperature, salinity, nitrates and chlorophyll a in Ría de Muros
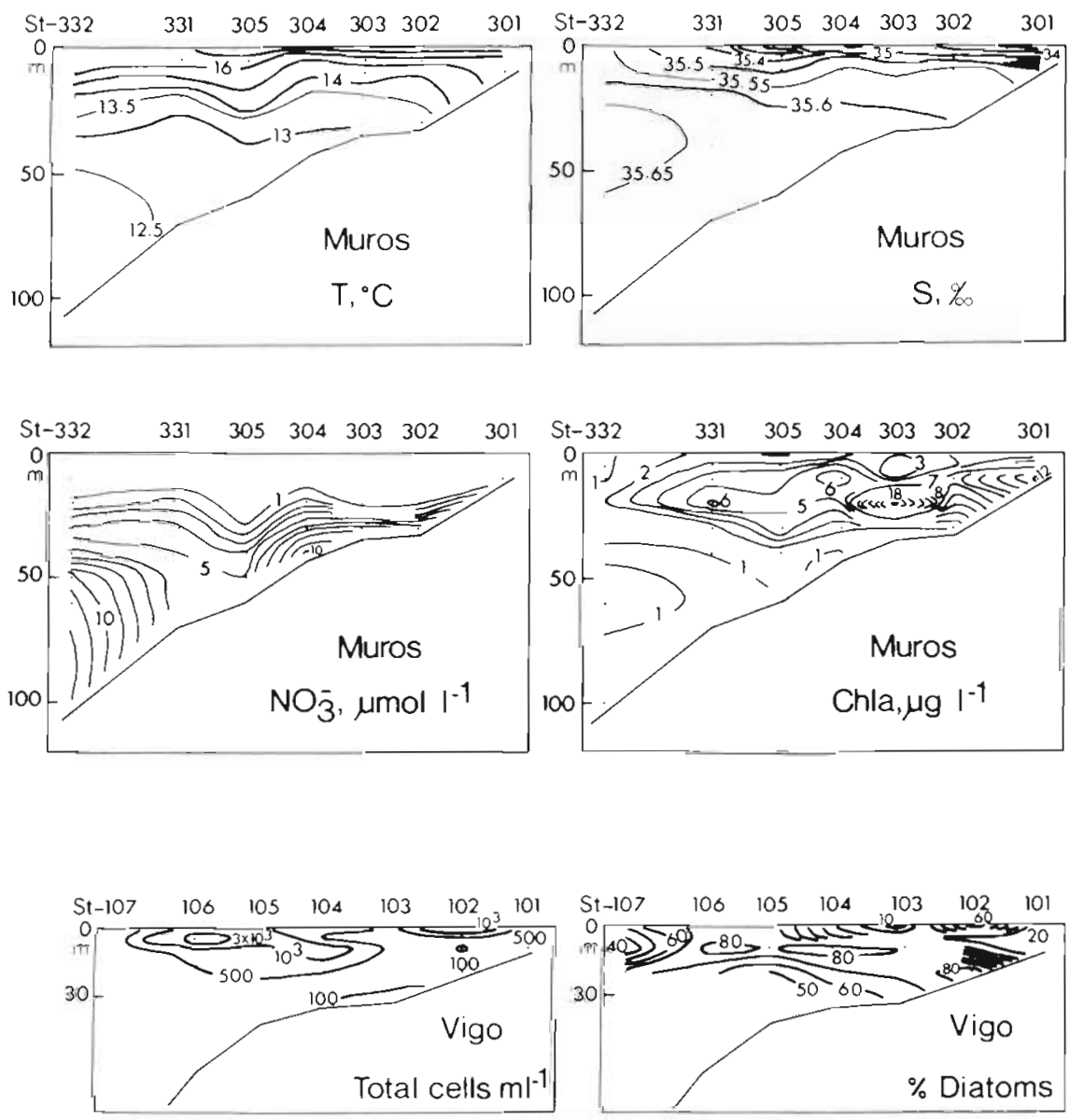

Fig. 5. Total cell concentrations, and percentage occupied by various phytoplankton groups, in Ría de Vigo
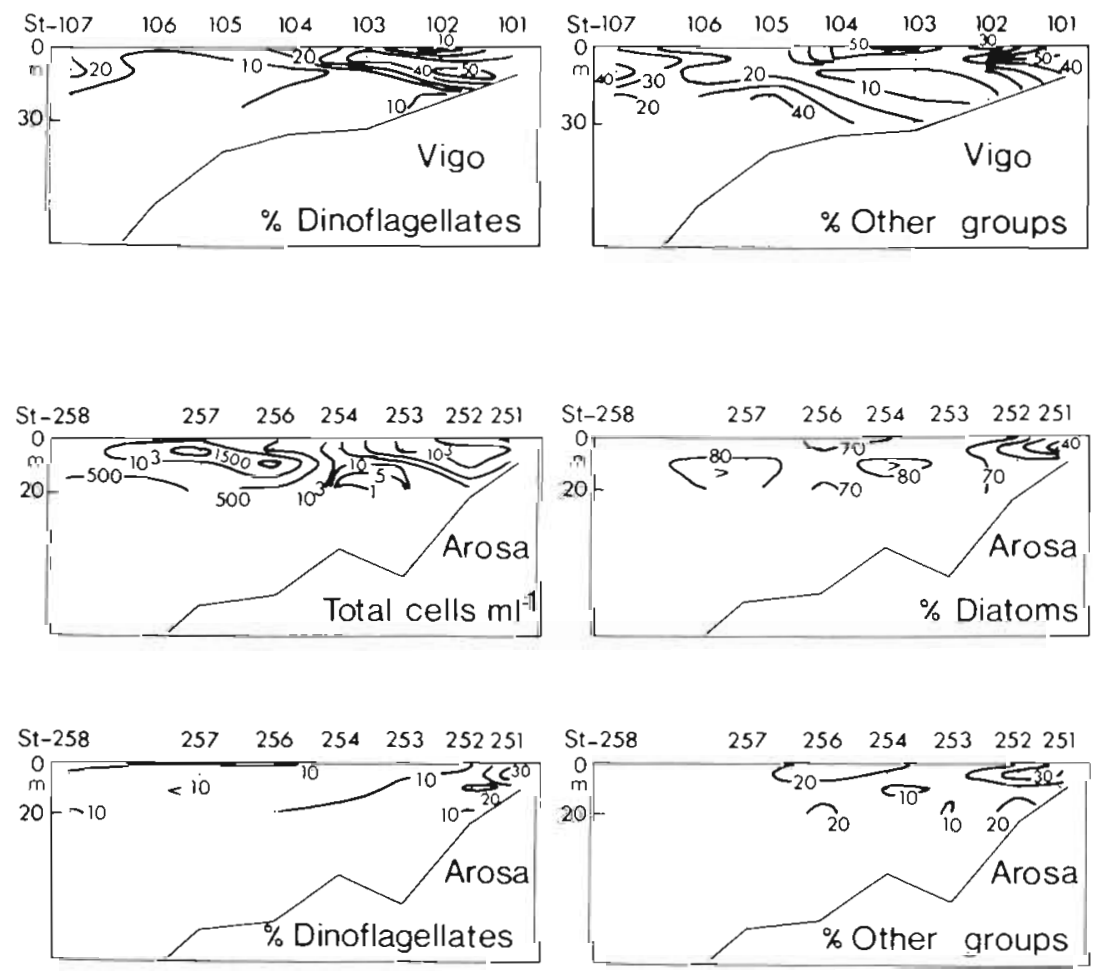

Fig. 6. Total cell concentrations, and percentage occupied by various phytoplankton groups, in Ría de Arosa 

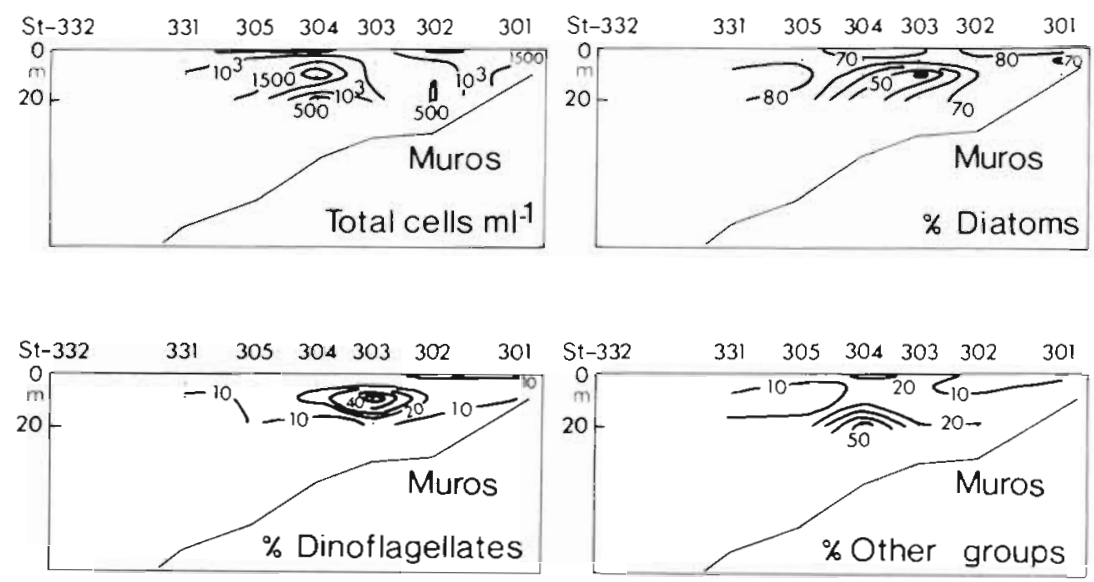

Fig. 7. Total cell concentrations, and percentage occupied by various phytoplankton groups, in Ría de Muros

ages greater than $80 \%$. The chlorophyll maxima in the Ria de Vigo were due to diatoms (Figs. 2 and 5), except at the surface of Stn 103, where Mesodinium rubrum ( $71 \%$ of total ciliates) was responsible for the chlorophyll concentrations observed (Fig. 8). M. rubrum was also the main ciliate at Stns 104 and 105, representing $89 \%$ of the total number of ciliates in the maximum at Stn 104, and $86 \%$ in that at Stn 105; the dinoflagellates were found at innermost stations, where cell numbers were not very high. Practically all the phytoplankton of Arosa was composed of diatoms (Fig. 6), and only in the 2 innermost stations did some small populations of dinoflagellates and other groups occur; the distribution of ciliates was parallel to that of chloropyll (Fig. 8), with $M$. rubrum representing 69 and $89 \%$ respectively of total ciliates in the maxima at Stns 256 and 257.

The phytoplankton of Muros was also almost entirely composed of diatoms (Fig. 7), except at some points, such as $10 \mathrm{~m}$ depth in Stn 303 where $57 \%$ of the cells were dinoflagellates, and $20 \mathrm{~m}$ depth in Stn 304 where $55 \%$ of the population were cells from other groups. Nevertheless, neither of these 2 points corresponded to cell maxima. Populations of Mesodinium rubrum contributed to chlorophyll maxima at Stns $303(20 \mathrm{~m})$ and $301(10 \mathrm{~m})$; here, this autotrophic ciliate reached concentrations of 85 and $88 \%$ respectively

\section{Multivariate statistical analyses}

PCA, performed with the 41 species or species groups present in at least $50 \%$ of the samples, extracted
4 components which explained $46.32 \%$ of the total variance: PC 1 explained 19.48\%, PC $213.72 \%$, PC 3 $7.72 \%$ and PC $45.40 \%$. The species are listed in Appendix 1 (ordered according to their correlation with PC 1); distributions of scores of the 4 components in the 3 rias are given in Figs. 9 to 11. All the species except 5 were positively correlated with PC 1 . This component had a correlation coefficient of 0.78 with the logarithm of the total number of cells (including ciliates), and its distribution, although not exactly equal to that of cell abundance, was quite close to it.

Nitzschia delicatissima, Rhizosolenia alata gracillina, Dinophysis acuminata, D. ovum, Ceratium horridum, Nitzschia seriata-like, Ceratium fusus, Dinophysis puntacta and Cochlodinium helix displayed the highest positive correlation $(r>0.40)$ with PC 2. Amphidinium curvatum. Thalassiosira rotula, Rhizosolenia hebetata semispina, Asterionella japonica and Rhizosolenia delicatula displayed the greatest negative correlations. This components distribution was characterized by the occurrence of positive scores in the more oceanic stations of the rías; at the same time, a clear difference could be seen among the 3 rías: Vigo had the highest positive scores and Arosa the highest negative, with Muros in an intermediate position.

PC 3 was defined on the positive side principally by Protoperidinium diabolus and medium-sized oligotrichous ciliates, and on the negative by Ceratium horridum and Schröderella delicatula schroderi. The scores of this component displayed a clear vertical
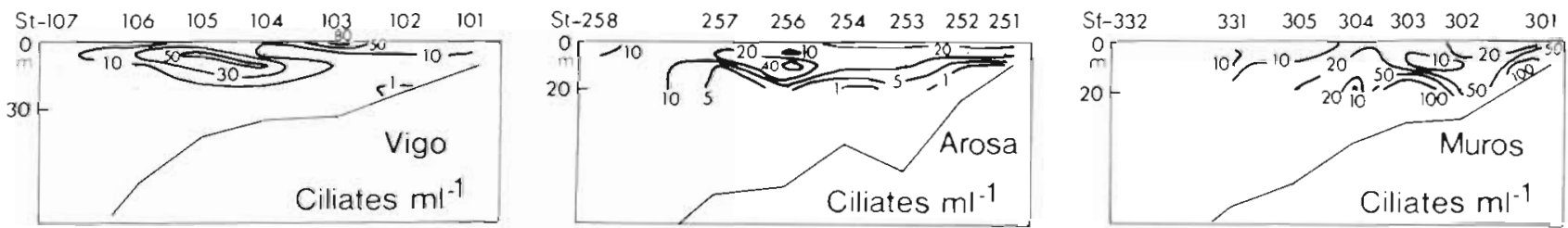

Fig. 8. Concentrations of ciliates (no. ind $\mathrm{ml}^{-1}$ ) in Rías de Vigo, Arosa and Muros 
Fig. 9. Distributions of scores of the first 4 principal components (PC 1 to PC 4) of phytoplankton in Ría de Vigo
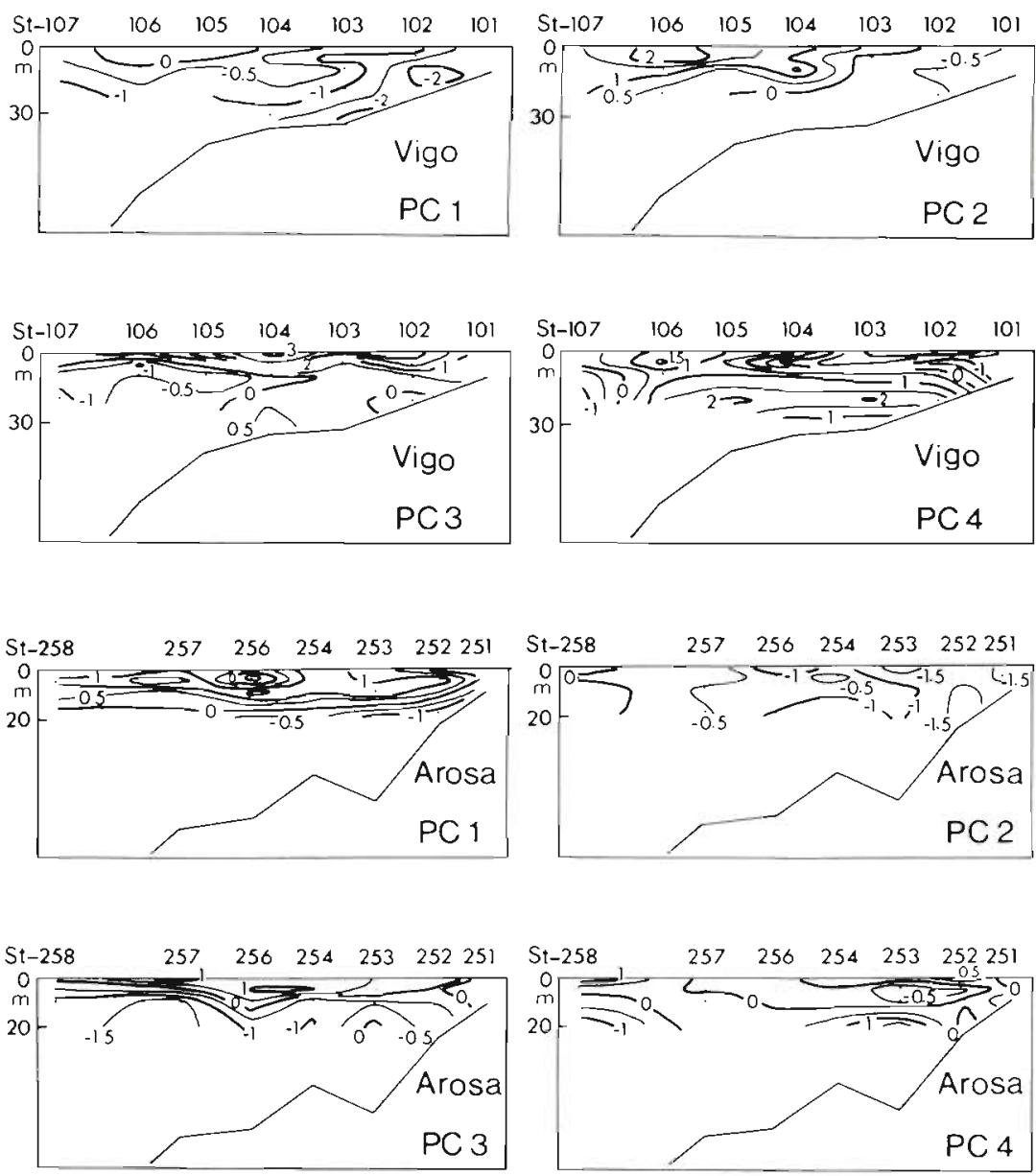

Fig. 10. Distributions of scores of the first 4 principal components (PC 1 to PC 4) phytoplankton in Ría de Arosa

Fig. 11. Distributions of scores of the first 4 principal components (PC 1 to PC 4) phytoplankton in Ría de Muros
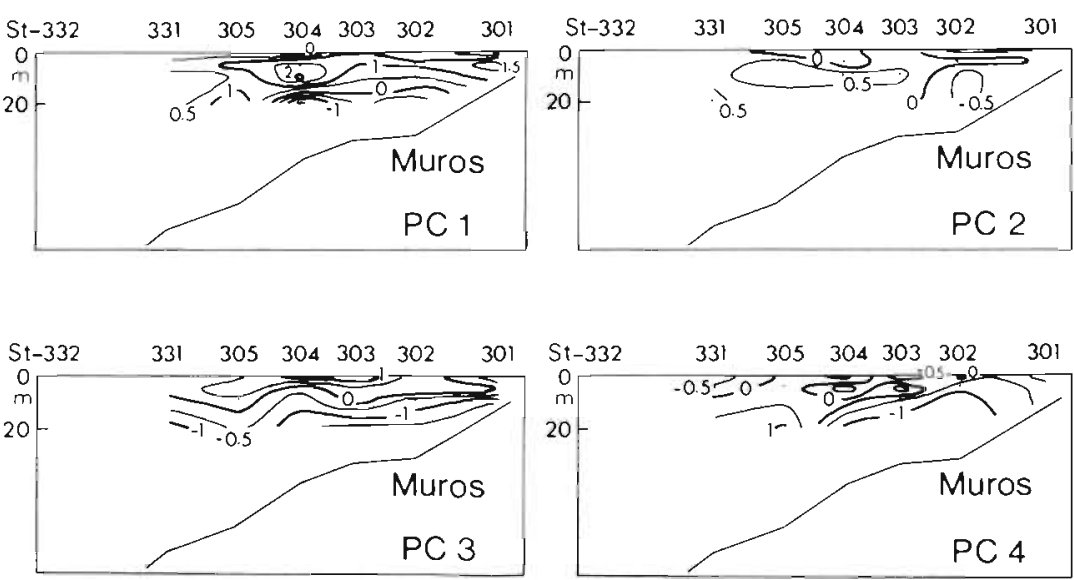

segregation, with the positive scores situated at the surface and the negative at depth. Nevertheless, Vigo and Arosa exhibited a trend in the negative scores towards the more oceanic stations, while those in Muros were more uniformly distributed. On the other hand, the highest positive and lowest negative scores were found in Vigo. Arosa and Muros did not have, in this respect, any notable difference between them.

Nitzschia seriata-like, Nitzschia longissima, Prorocentrum balticum, Chaetoceros spp., Asterionella japonica, Nitzschia delicatissima and Chaetoceros didymus displayed the greatest positive correlation 
with $\mathrm{PC} 4(\mathrm{r}>0.30)$. Protoperidinium diabolus, medium-size peritrichous ciliates, Scrippsiella trochoidea and faeroense, and Protoperidinium cerasus had the highest negative correlation. In the Ría de Vigo maximal scores occurred in the bottom samples, and extended to the surface at Stn 106. In this station the maximum coincided with that of chlorophyll (Fig. 2), while in the other stations the maximal scores were found below. In Arosa the pattern of score distribution was similar but, in contrast to Vigo, PC 4 also displayed positive values at the surface in the inner stations (Stns 252, 253 and 254). In Muros, as in the other 2 rías, the secondary chlorophyll maxima coincided to a certain extent with the positive scores of $\mathrm{PC} 4$, except for the principal chlorophyll maximum at Stn 303, where the scores were negative.

Cluster analysis yielded 3 clusters of more than 2 species group (with a correlation greater than 0.5); within 2 of these clusters another 2 occurred for which the correlation was greater than 0.7 (Fig. 12). As shown in Fig. 12, these clusters were well defined within the plane formed by the first 2 principal components. The values of each cluster in the rías are given in Appendices 2, 3 \& 4. Cluster $A_{1}$ formed by Asterionella japonica, Rhizosolenia hebetata semispina and Thalassiosira rotula, was present in all except 4 of the Ría de Arosa samples. In contrast, this cluster was not present in any Vigo sample. In Muros there were only 6 samples containing this cluster. Cluster B, formed by Rhizosolenia delicatula, Protoperidinium cerasus and small flagellates, was observed in $55 \%$ of the samples from Arosa and Muros, while only 1 Vigo sample contained this cluster. Although Cluster $C_{\text {, formed by }}$ Ceratium fusus, Dinophysis acuminata, Dinophysis ovum and Dinophysis puntacta, was more frequent in Arosa and Muros than in Vigo 445,57 and $33 \%$ respectively), its values were greater in Vigo (maximum val-

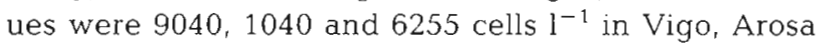
and Muros respectively). While in Muros Cluster C extended throughout the entire ría, in Arosa and Vigo it was localized to the more oceanic stations.

CCA yielded 3 pairs of significant canonical variables ( $p<0.01$ ) according to the Bartlett test, the first pair with a canonical correlation of 0.91 , the second 0.82 and the third 0.55. As shown in Table 2, the physico-chemical variables displaying higher positive correlations with the first canonical variable were oxygen, $\mathrm{pH}$ and chloropyll, while all the nutrients displayed negative correlations. The first pair of canonical variables was correlated with PC 1 and PC 2. Temperature, $\mathrm{pH}$ and oxygen were positively correlated with the second canonical variable, while the rest of the physico-chemical variables showed insignificant negative correlations. Only PC 3 displayed an important correlation, which was positive. Salinity and nitrites

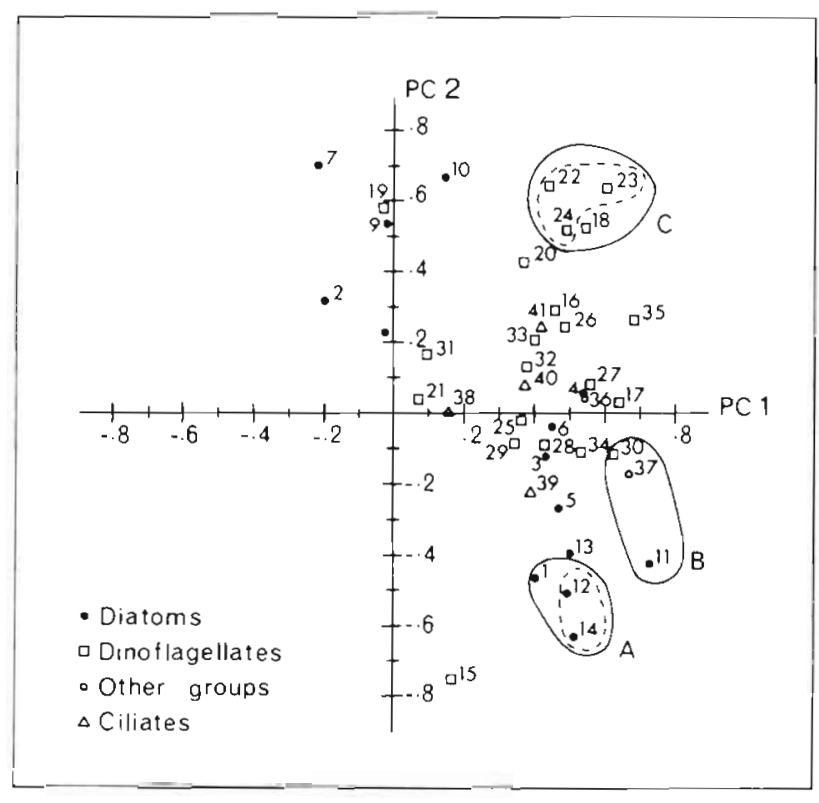

Fig. 12. Position of the extremes of 41 species vectors in the space determined by the first and second principal components. Continuous lines enclose clusters (A, B, C) with a correlation greater than 0.5 ; dashed lines enclose those with a correlation greater than 0.7. Number key: (1) Asterionella japonica, (2) small centric diatoms, (3) Chaetoceros didymus, (4) Chaetoceros spp., (5) Chaetoceros spp., small, (6) Leptocylindrus danicus + minimus, (7) Nitzschia delicatissima, (8) Nitzschia longissima, (9) Nitzschia seriata + pungens-like, (10) Rhizosolenia alata gracillina, (11) Rhizosolenia delicatula, (12) Rhizosolenia hebetata semispina, (13) Schröederella delicatula, (14) Thalassiosira rotula, (15) Amphidinium curvatum, (16) Amphidinium flagellans, (17) Cachonina niei, (18) Ceratium fusus, (19) Ceratium horridum, (20) Cochlodinium helix, (21) medium-sized naked dinoflagellates, (22) Dinophysis acuminata, (23) Dinophysis ovum, (24) Dinophysis puntacta, (25) Gymnodinium(?) nanum, (26) Gymnodinium spp., medium, (27) Gymnodinium spp., small, (28) Gymnodinium varians(?), (29) Prorocentrum balticum, (30) Protoperidinium cerasus, (31) Protoperidinium diabolus + longipes, (32) Protoperidinium mite, (33) Protoperidinium(?) spp., small, (34) Protoperidinium steinii, (35) Scrippsiella trochoidea + faeroense, (36) small flagellates, (37) Heterosigma akashiwo, (38) medium-sized oligotrichous ciliates, (39) small oligotrichous ciliates, (40) medium-sized peritrichous ciliates, (41) Mesodinium rubrum

were the original variables exhibiting the greatest positive correlation with the third pair, while chlorophyll showed a correlation of -0.60 . Among the principal components, PC 2, PC 3 and PC 4 show positive correlations, and PC 1 negative.

\section{DISCUSSION}

Although the presence of SCMs, their phytoplankton composition and other relevant ecological aspects have been observed and studied in a great variety of oceanic 
Table 2. Correlations of pairs of canonical variables (V1 to V3), and correlations of the canonical variables (LV1 to LV3) with the original variables for canonical correlation analysis of principal phytoplankton components and physico-chemical variables $(p<0.01$; Bartlett's test)

\begin{tabular}{|lrrr|}
\hline Canonical variables: & V1 & V2 & \multicolumn{1}{c|}{ V3 } \\
Canonical correlation: & 0.91 & 0.82 & 0.55 \\
& LV1 & LV2 & LV3 \\
\hline PC 1 & 0.78 & 0.12 & -0.39 \\
PC 2 & 0.58 & -0.12 & 0.74 \\
PC 3 & -0.11 & 0.91 & 0.33 \\
PC 4 & -0.19 & -0.38 & 0.44 \\
Temperature & 0.18 & 0.92 & -0.11 \\
Salinity & 0.05 & -0.34 & 0.24 \\
pH & 0.81 & 0.51 & 0.10 \\
Oxygen & 0.81 & 0.50 & 0.05 \\
Nitrates & -0.60 & -0.36 & 0.09 \\
Nitrites & -0.73 & -0.34 & 0.21 \\
Phosphates & -0.90 & -0.13 & -0.15 \\
Silicates & -0.87 & -0.18 & 0.01 \\
Chlorophyll & 0.37 & -0.25 & -0.60 \\
\hline
\end{tabular}

areas (e.g. Saijo et al. 1969, Revelante \& Gilmartin 1973, Venrick et al. 1973, Kiefer et al. 1976, Cullen \& Eppley 1981, Cullen et al. 1982, Furuya \& Marumo 1983, Estrada 1985a, b, Venrick 1988, Estrada \& Salat 1989), there is a lack of related observations for the Galician upwelling. The few data which exist (Mouriño et al. 1985, Figueiras \& Niell 1987a, b, Fraga et al. 1987) indicate that, when the upwelling stops, an SCM is formed in the ocean and the rias, and that this is located at a depth of ca $50 \mathrm{~m}$ in the ocean and between 10 and $30 \mathrm{~m}$ in the interior of the rias. Little or nothing is known about other aspects related to this maximum, such as phytoplankton composition.

The results given here indicate that from the end of July to the beginning of August 1984 coastal upwelling had ceased, as suggested by the horizontal distribution of temperature, salinity and nitrate isolines. Despite this, due to the estuarine circulation in the rias, nutrient-rich water entered them along the bottom, without reaching the surface. The topography of the bottom, which rapidly steepened in the Rías de Vigo and Arosa, and the probable eddy-circulation characteristics of these places involving confluence of surface and bottom waters (Figueiras et al. 1985, Fraga \& Prego 1989) produced some slight shallowings and deepenings in temperature and salinity isolines. However, these features were much clearer in the nitrate distributions.

There were some differences in salinity distributions among the 3 rías. Vigo and Muros were more stratified than Arosa (Figs. 2 to 4). Arosa showed strong haline stratification only at the 3 innermost stations. This fact must be related to its geomorphology, with a higher width:length ratio oceanward from Stn 253 (Fig. 1 and Table 1). The haline stratification in Muros was due to the fact that riverine contribution was highest in this ría (Table 1).

As a result of weak coastal upwelling, distribution of nitrates showed a very apparent gradient. Above this nutricline a chlorophyll maximum was found.

Chlorophyll maxima corresponded to phytoplankton cell maxima, in which the diatoms were the most abundant group. The proportion of dinoflagellates was small and was $>50 \%$ only at the 3 innermost stations in the Ría de Vigo and at $10 \mathrm{~m}$ depth at Stn 303 in Muros. In Arosa dinoflagellates composed less than $10 \%$ of the phytoplankton in the majority of the ria and, as with Vigo, attained greater abundances only in the interior parts. Distributions similar to these, with a tendency for dinoflagellates to occur in the interior, have already been found on other occasions in the rías (Figueiras \& Niell 1987b) and have been attributed to a higher degree of heterotrophy in these areas. The presence of other groups, dominated by small flagellates, was important only in the Ría de Vigo. In Arosa they were hardly represented, and only in the interior did they attain more than $30 \%$. In Muros, a similar mode was found for the dinoflagellates, in that they were concentrated into small areas. Of the 3 rías, Vigo had the most structured and complex community, which is in agreement with its stable hydrographic regime, low fluvial contribution and high thermal and haline stratification. Arosa seems to have had the greatest water mixing, judging by the salinity distribution oceanward from Stn 253, which corresponds to the widest part of this zone and has a higher width:length ratio than the mean ratio for the entire ría (Table 1). Muros displayed the most intense surface flow. Both factors, mixing and surface flow, must act in favour of species with a greater growth rate (diatoms) and hamper the formation of complex trophic relations within the system (Margalef 1978. Margalef et al. 1979).

The ciliate Mesodinium rubrum also significantly contributed to the presence of an SCM; this ciliate is made visible by its red stains where it accumulates at the surface (Mouriño et al. 1985). Taking into account the kind of sampling used and the swimming capacity of this organism (Barber \& Smith 1981), as well as its tendency to aggregate in very narrow layers and the underestimates that are surely made during counting in samples fixed with Lugol's solution (see revision of Crawford 1989), it is very likely that the contribution of M. rubrum was underestimated. The estimates of abundance given here agree with those of Crawford (1989). On the other hand, it has been known for a long time that $M$. rubrum is one of the organisms responsible for the formation of red tides in the Ría de Vigo (Margalef 1956), and often, during summer, intense 
red-coloured stains appear in which $M$. rubrum is the most abundant species (Fraga 1989). M. rubrum is typical of upwelling areas (Packard et al. 1978) and zones of the rías where a certain amount of mixing with coastal water and strong stratification occur (Margalef 1956, Margalef et al. 1979), and together with diatoms contributes to chlorophyll maxima; its presence indicates that the exchange rate of the rias with the ocean and/or the intensity of mixing were relatively important (Margalef et al. 1979). We emphasize that the greatest accumulation of $M$. rubrum in the 3 rías occurred in areas with depressed temperature and nitrate isolines adjoining shallow ones (compare Figs. 2, 3 \& 4 with Fig. 8). This suggests a mechanism similar to that proposed by Packard et al. (1978) for cellular aggregation, whereby $M$. rubrum resists the descending current in places adjoining areas of ascending water; this could explain the accumulation of this species at Stns 105 and 104 in Vigo, Stn 256 in Arosa, and the bottom of Stn 303 in Muros.

There is a lack of synoptic simultaneous data which would allow us to ascertain if there is also a similar phytoplankton accumulation of this kind on the ocean side. At $20 \mathrm{~m}$ depth at $\operatorname{Stn} 258$ in Arosa, just above the chlorophyll maximum $\left(16.8 \mu \mathrm{g} 1^{-1}\right.$; Fig. 3), the concentration of $M$. rubrum was 10370 cells $)^{-1}$ (55\% of the total for ciliates), suggesting that the accumulation must be produced on both sides of the doming at Stn 257 in Arosa, contributing to the oceanic chlorophyll maximum.

PCA confirms the above conclusions, in that the Ría de Arosa was the least structured (with a lesser niche differentiation) of the 3 rías. Morever, it permits other conclusions about the composition and distribution of phytoplankton.

PC 1, which explained to a large extent the variation due to differences in cell abundance, indicated that phytoplankton composition was very diverse (as can be seen from the great number of species that defined it; Appendix 1); these species correspond to periods between upwellings (Figueiras \& Niell 1987b), when diatoms coexist with a great number of dinoflagellates, various flagellates and ciliates. Some of these species (e.g. Scrippsiella trochoidea, Heterosigma akashiwo, Cachonina niei, Ceratium fusus, Mesodinium rubrum] are capable of forming red tides.

PC 2, which separates oceanic species from others which are markedly neritic, confirmed the differences between the 3 rias: Arosa was the most mixed of the 3 , with a clear neritic influence, and diatoms were important; in Muros oceanic species were present in a subsurface layer, just below the freshwater layer; in Vigo a clear separation between stations in the interior and those of the exterior was revealed.

PC 3, which clearly displayed a vertical gradient in the 3 rias (Figs. 9 to 11), indicated that a community of markedly heterotrophic character existed at the surface (Gaines \& Taylor 1984, Lessard \& Swift 1986, Gaines \& Elbrächter 1987); in the deeper samples the community was formed by chlorophyll-containing species, in particular the dinoflagellates Ceratium horridum and Ceratium fusus and the ciliate Mesodinium rubrum, 3 species that can form appreciable chlorophyll patches. The distribution of this component again confirmed the difference between the 3 rías. Thus, in Vigo these 3 species contributed to the chlorophyll maximum in the outermost stations, and in Arosa they were distributed slightly below the chlorophyll maximum and tended to be located in the more oceanic stations. The same species contributed to the SCM of Muros but increased throughout this ría possibly because of the abundance of $M$. rubrum in the interior.

The distributions of PC 4 indicated that the group of diatoms with positive loads (Nitzschia seriata-like, Nitzschia longissima, Chaetoceros spp., Asterionella japonica, Nitzschia delicatissima, Chaetoceros didymus) were found in the interior of the Rías de Vigo and Arosa below the SCM, reaching the surface at Stns 106 and 107 in Vigo and at Stns 258, 251 and 252 in Arosa; in all these locations there were shallowings of nitrate isolines. These species, together with others, have been identified before for the Rías Baixas (Figueiras \& Niell $1987 \mathrm{~b}$ ) as typical of periods of high nutrient concentrations brought about by upwelling, and therefore their occurrence below the SCM, where nutrients were present, is not surprising (Figs. 2 to 4). The negative values of this component below the SCM on the riverine side of Stn 304 at Muros could have been due to the high concentrations of small flagellates and ciliates (including Mesodinium rubrum), which correlated negatively with PC 4 (Appendix 1).

Cluster analysis also confirmed the results obtained with PCA (Fig. 12). Cluster A (formed by 3 abundant diatoms, as indicated by their loads with $\mathrm{PC}$ 1) was present in Arosa, slightly less extensive in Muros and absent in Vigo, strengthening the conclusion that Arosa was the most mixed ria and Vigo the least, with Muros in an intermediate position. The absence of Cluster B [made up of Protoperidinium cerasus and small flagellates, typical of weak upwellings or of post-upwelling periods, together with the diatom Rhizosolenia delicatula, characteristic of upwellings (Figueiras \& Niell 1987b)] in the Ría de Vigo is consistent with this conclusion. The majority of species forming Cluster $\mathrm{C}$ are morphologically flattened and, therefore, belong to very stratified waters (Margalef 1978). Nevertheless, the presence of Ceratium fusus in the cluster indicates that red tides might occur in these waters. The proximity of Cochlodinium helix, Scrippsiella trochoidea-like, and Mesodinium rubrum to this cluster (Fig. 12) appears to 
confirm this hypothesis. Although the cluster was present in the 3 rias, it had the highest values in Vigo, corresponding to stratified waters.

The canonical structure revealed by CCA (Table 2) indicates that the assemblages defined by $\mathrm{PC} 1$ and $\mathrm{PC}$ 2 appeared after a production stage in which some heterotrophic relations had already begun to be established. This conclusion is supported by the relationship of the physico-chemical variables to the first pair of canonical variables, where $\mathrm{pH}$ and oxygen (2 variables which reflect the recent history of a system) had a positive correlation and all the nutrients a negative correlation. Chlorophyll displayed a positive but not very high correlation, probably due to its consumption through grazing. The second pair of canonical variables showed that the assemblage defined by PC 3 , which is strongly heterotrophic (Lessard \& Swift 1986), is present after production events and/or at locations distant from those events, where the waters are warmer and some regeneration of nutrients occurs. This last point is confirmed by the correlations of $\mathrm{pH}$, oxygen and nutrients, which are lower than in the first pair of canonical variables. The relative exclusion shown by the assemblages defined by PC 3 and PC 4 in the second pair of canonical variables has some relation with their complementary distribution, with the PC 4 assemblage being located in waters richer in nutrients.

Table 3 summarizes the principal morphological, hydrographic and biological characteristics found in the 3 rías.

Similarly to other shallow waters (Vandevelde et al.
1987), an SCM is found in the Galician Rias Baixas during summer and at times of reduced coastal upwelling. This maximum may be related to a deep ocean maximum, which is found at the same times. The estuarine circulation and shallow depth in the rías would elevate this SCM to depths of between 10 and $20 \mathrm{~m}$.

In the present study the SCM consisted mainly of diatoms, among which there were species from periods of intense upwelling, together with others characteristic of stratification. At some places, other relatively large, potentially red-tide forming species, such as the ciliate Mesodinium rubrum and the dinoflagellates Ceratium horridum and Ceratium fusus, were occasionally found in the SCM. Above the SCM 2 distinct assemblages were found. One consisted of flat dinoflagellates and some elongated diatoms, and had a more oceanic distribution. The other, dominated by round forms without chlorophyll, had a distribution that covered the whole upper layer. A similar distinction between phytoplankton composition in the upper layers and in the SCM has been shown for other areas (Venrick et al. 1973, Cullen et al. 1982, Furuya \& Marumo 1983, Estrada 1985a, Estrada \& Salat 1989). Nevertheless, in this case, the presence of 2 different assemblages suggests that some interchange between the ocean and the rias, 2 zones of differing phytoplankton composition, must exist.

Below the SCM, a third assemblage of diatoms with a clearly neritic distribution was found in the 3 rías. This suggests a vertical segregation of the diatoms. Some of these contributed to the formation of the SCM, and

Table 3. Summary of geomorphological characteristics and principal hydrographic and biological features of the Rías de Vigo, Arosa and Muros. SCM: subsurface chlorophyll maximum; chl a: chlorophyll $a_{i}$ Di: diatoms; Df: dinoflagellates; Oth: other groups

\begin{tabular}{|c|c|c|c|}
\hline & Vigo & Arosa & Muros \\
\hline Width: length & 0.16 & 0.37 & 0.38 \\
\hline$r_{j}(\mathrm{~km})$ & 2.28 & 4.50 & 6.81 \\
\hline Tidal excursion (m) & 3.23 & 3.03 & 2.08 \\
\hline Range of surface temp. $\left({ }^{\circ} \mathrm{C}\right)$ & $15.8-19.5$ & $15.9-18.4$ & $16.8-18.4$ \\
\hline Range of vertical temp $\left({ }^{\circ} \mathrm{C}\right)$ & $12.1-19.5$ & $12.1-18.4$ & $12.2-16.8$ \\
\hline Range of surface salinity (\%a) & $34.9-35.5$ & $34.7-35.5$ & $31.4-35.7$ \\
\hline Range of vertical salinity (\%o) & $34.9-35.7$ & $34.7-35.7$ & $31.4-35.6$ \\
\hline Depth of top of nitracline (m) & $10-20$ & $10-30$ & 20 \\
\hline Depth of SCM $(\mathrm{m})$ & $5-10$ & $5-30$ & $10-20$ \\
\hline Range of chl a conc. at SCM $\left(\mu \mathrm{gl}^{-1}\right)$ & $6-11$ & $8-16$ & $6-18$ \\
\hline Major phytoplankton types & Di; Df; Oth & Di & Di; Df; Oth \\
\hline \multicolumn{4}{|l|}{ Range of principal components } \\
\hline PC 1 & $-2.2 ; 0.5$ & $-1.6 ; 1.9$ & $-1.6 ; 2.1$ \\
\hline $\mathrm{PC} 2$ & $-0.8 ; 2.5$ & $-1.7 ; 0.4$ & $-0.6 ; 0.8$ \\
\hline $\mathrm{PC} 3$ & $-2.4 ; 3.1$ & $-1.7 ; 1.2$ & $-1.6 ; 1.5$ \\
\hline $\mathrm{PC} 4$ & $-2.9 ; 2.1$ & $-1.5 ; 2.0$ & $-1.4 ; 1.0$ \\
\hline \multicolumn{4}{|l|}{ Range of clusters (cells l ${ }^{-1}$ ) } \\
\hline Cluster A & $0 ; 0$ & $0 ; 28147$ & $0 ; \quad 4507$ \\
\hline Cluster B & $0 ; 3807$ & $0 ; 26347$ & $0 ; 21820$ \\
\hline Cluster C & $0 ; 9040$ & $0 ; 1040$ & $0 ; \quad 6255$ \\
\hline
\end{tabular}


others were located in deeper waters with greater concentrations of nutrients.

The relationship between the physico-chemical environment and the phytoplankton assemblages suggests that the formation of SCMs in the rias is a dynamic process resulting from the interaction among intermittent upwelling, associated circulation and the response of phytoplankton. Here again, the clear vertical segregation that exists among species which exhibit completely different modes of nutrition (heterotrophy at the surface, autotrophy at greater depths) indicates that, in the same way that there is a horizontal separation of communities in upwelling systems, there can be a vertical segregation and succession of communities when an SCM is established.
Acknowledgements. Our gratitude to all those who took part in the Galicia VIII cruise of RV 'Garcia del Cid' and 1 anonymous reviewer for comments on the first version of the manuscript. T Rellan and R. Penin helped produce the figures. River volumes were supplied by the Confederación Hidrográfica del Norte This work was subsidized by project C-30019/81 of the Comisión Asesora de Investigación Cientifica y Técnica.

\section{LITERATURE CITED}

Barber, R. T., Smith, W O. (1981). The role of circulation, sinking and vertical migration in physical sorting of phytoplankton in the upwelling centre at $15^{\circ} \mathrm{S}$. In: Richards, F. A (ed.) Coastal upwelling. American Geophysical Union Washington, D.C., p. 366-371

Blanton, J. O., Atkinson, P. L., Fernández de Castillejo, F.

Appendix 1. Correlation coefficients of the species and taxa selected for principal component analysis with the first 4 principal components. Species ordered according to their correlation with PC 1

\begin{tabular}{|c|c|c|c|c|}
\hline \multirow[t]{2}{*}{ Taxon } & \multicolumn{4}{|c|}{ Components } \\
\hline & 1 & 2 & 3 & 4 \\
\hline Rhizosolenia delicatula & 0.73 & -0.43 & -0.04 & -0.07 \\
\hline Scrippsiella trochoidea + faeroense & 0.68 & 0.26 & 0.12 & -0.33 \\
\hline Heterosigma akashiwo & 0.67 & -0.18 & -0.31 & -0.03 \\
\hline Cachonina niei & 0.64 & 0.02 & 0.20 & -0.03 \\
\hline Protoperidinium cerasus & 0.63 & -0.12 & 0.02 & -0.30 \\
\hline Dinophysis ovum & 0.60 & 0.64 & 0.05 & -0.09 \\
\hline Gymnodinium spp., small & 0.56 & 0.08 & 0.30 & 0.16 \\
\hline Small flagellates & 0.54 & 0.04 & 0.27 & -0.23 \\
\hline Ceratium fusus & 0.54 & 0.52 & -0.35 & -0.06 \\
\hline Chaetoceros spp. & 0.54 & 0.05 & -0.25 & 0.41 \\
\hline Protoperidinium steinii & 0.53 & -0.12 & 0.32 & 0.14 \\
\hline Thalassiosira rotula & 0.52 & -0.63 & -0.18 & -0.10 \\
\hline Schröederella delicatula & 0.50 & -0.39 & -0.41 & -0.04 \\
\hline Rhizosilenia hebetata semispina & 0.50 & -0.51 & -0.05 & 0.23 \\
\hline Dinophysis punctata & 0.49 & 0.52 & 0.23 & 0.01 \\
\hline Gymnodinium spp., medium & 0.49 & 0.24 & -0.11 & -0.10 \\
\hline Chaetoceros spp., small & 0.47 & -0.27 & -0.33 & -0.10 \\
\hline Amphidinium flagellans & 0.45 & 0.29 & -0.23 & 0.01 \\
\hline Leptocylindrus danicus + minumus & 0.45 & -0.04 & 0.12 & 0.24 \\
\hline Dinophysis acuminata & 0.44 & 0.64 & -0.01 & -0.02 \\
\hline Chaetoceros didymus & 0.43 & -0.13 & -0.25 & 0.31 \\
\hline Gymnodinium varians(?) & 0.42 & -0.10 & 0.16 & 0.16 \\
\hline Mesodinium rubrum & 0.41 & 0.25 & -0.36 & -0.17 \\
\hline Asterionella japonica & 0.41 & -0.47 & -0.10 & 0.40 \\
\hline Protoperidinum(?) spp., small & 0.40 & 0.20 & 0.15 & -0.13 \\
\hline Small oligotrichous ciliates & 0.39 & -0.23 & -0.08 & -0.02 \\
\hline Protoperidium mite & 0.38 & 0.13 & 0.26 & -0.11 \\
\hline Medium peritrichous ciliates & 0.37 & 0.08 & -0.06 & -0.38 \\
\hline Cochlodinium helix & 0.37 & 0.43 & 0.36 & 0.21 \\
\hline Gymnodinium(?) nanum & 0.37 & -0.02 & 0.12 & -0.01 \\
\hline Prorocentrum balticum & 0.35 & -0.09 & 0.34 & 0.45 \\
\hline Amphidinium curvatum & 0.16 & -0.75 & 0.26 & -0.01 \\
\hline Medium oligotrichous ciliates & 0.16 & 0.01 & 0.62 & -0.07 \\
\hline Rhizosolenia alata gracillina & 0.15 & 0.67 & -0.34 & 0.04 \\
\hline Protoperidinium diabolus + longipes & 0.09 & 0.16 & 0.72 & -0.38 \\
\hline Medium naked dinoflagellates & 0.07 & 0.03 & -0.00 & 0.30 \\
\hline Nitzschia seriata + pungens-like & -0.02 & 0.53 & 0.07 & 0.50 \\
\hline Nitzschia longissima & -0.02 & 0.23 & 0.17 & 0.49 \\
\hline Ceratium horridum & -0.03 & 0.58 & -0.56 & -0.12 \\
\hline Small centric diatoms & -0.20 & 0.32 & 0.28 & 0.15 \\
\hline Nitzschia delicatissima & -0.22 & 0.70 & -0.08 & 0.34 \\
\hline
\end{tabular}


Lavín Montero, A. (1984). Coastal upwelling off the Rías Bajas, Galicia, Northwest Spain, I: Hydrography studies. Rapp. P.-v. Réun. Cons. int. Explor. Mer 183: 79-90

Crawford, D. W. (1989). Mesodinium rubrum: the phytoplankter that wasn't. Mar. Ecol. Prog. Ser. 58: 161-174

Cullen, J. J., Eppley, R. W. (1981). Chlorophyll maximum layers of the Southern California Bight and possible mechanisms of their formation and maintenance. Oceanol. Acta $4: 23-32$

Cullen, J. J., Reid, F. M. H., Stewart, E. (1982). Phytoplankton in the surface and chlorophyll maximum of southern California in August, 1978. J. Plankton Res. 4: 665-694

Durán, M., Sáiz, F., López-Benito, M., Margalef, R. (1956). El fitoplancton de la Ría de Vigo, de abril de 1954 a junio de 1955. Investigación pesq. 4: 67-95

Estrada, M. (1984). Phytoplankton distribution and composition off the coast of Galicia (northwest of Spain). J. Plankton Res. 6: 417-434

Appendix 2. Values of Clusters A, B and C $\left(\right.$ cells $\left.1^{-1}\right)$ in the Ría de Vigo

\begin{tabular}{|c|c|c|c|}
\hline \multirow[t]{2}{*}{ Stn: Depth (m) } & \multicolumn{3}{|c|}{ Clusters } \\
\hline & A & B & $\mathrm{C}$ \\
\hline 101:0 & - & - & - \\
\hline 10 & - & - & - \\
\hline 102: 0 & - & - & - \\
\hline 5 & - & - & - \\
\hline 10 & - & - & - \\
\hline 20 & - & - & - \\
\hline 103: 0 & - & - & 60 \\
\hline 5 & - & - & - \\
\hline 10 & - & - & -- \\
\hline 20 & - & - & - \\
\hline 30 & - & - & - \\
\hline 104:0 & - & - & 760 \\
\hline 5 & - & - & - \\
\hline 10 & - & - & - \\
\hline 20 & - & - & - \\
\hline 30 & - & - & - \\
\hline 105:0 & - & - & 7760 \\
\hline 5 & - & - & - \\
\hline 10 & - & - & - \\
\hline 20 & - & - & - \\
\hline 106: 0 & - & - & 4200 \\
\hline 5 & - & - & 5780 \\
\hline 10 & - & - & 630 \\
\hline 20 & - & - & - \\
\hline 107: 0 & - & - & 2815 \\
\hline 5 & - & - & - \\
\hline 10 & - & - & - \\
\hline 20 & - & - & 55 \\
\hline 108: 0 & - & - & - \\
\hline 5 & - & - & 3430 \\
\hline 10 & - & - & 1820 \\
\hline 20 & - & - & - \\
\hline 109: 0 & - & - & 6015 \\
\hline 5 & - & - & 9040 \\
\hline 10 & - & 3807 & - \\
\hline 20 & - & - & - \\
\hline
\end{tabular}

Estrada, M. (1985a). Deep phytoplankton and chlorophyll maxima in the Western Mediterranean. In: MoraitouApostolopoylou, M., Kiortsis, V. (eds.) Mediterranean marine ecosystems. Plenum Press, New York, p. 247-277

Estrada, M. (1985b). Primary production at the deep chlorophyll maximum in the Western Mediterranean. In: Gibbs, P. E. (ed.) Proceedings of the 19th European Marine Biology Symposium. Cambridge University Press, Cambridge, p. 109-121

Estrada, M., Salat, J. (1989). Phytoplankton assemblages of deep and surface water layers in a Mediterranean frontal zone. In: Ros, J. D. (ed.) Topics in marine biology. Scientia mar. 53: 203-214

Figueiras, F. G., Fraga, F. (1990). Vertical nutrient transport during proliferation of Gymnodinium catenatum Graham in Ría de Vigo, Northwest Spain. In: Granéli, E., Sundström, B., Edler, L., Anderson, D. M. (eds.) Toxic marine phytoplankton. Elsevier, New York, p. 144-148

Figueiras, F. G., Niell, F. X. (1986). Visibilidad del disco de Secchi, clorofila a y materia orgánica particulada en la ría de Pontevedra (NO de España). Invesigación pesq. 50: 607-637

Appendix 3. Values of Clusters A, B and C (cells $1^{-1}$ ) in the Ría de Arosa

\begin{tabular}{|c|c|c|c|}
\hline \multirow[t]{2}{*}{ Stn: Depth $(\mathrm{m})$} & \multicolumn{3}{|c|}{ Clusters } \\
\hline & A & B & $\mathrm{C}$ \\
\hline 251: 0 & 3853 & - & - \\
\hline 5 & 15353 & - & - \\
\hline 10 & 21187 & - & - \\
\hline 252: 0 & 28147 & - & - \\
\hline 5 & 25060 & 21933 & - \\
\hline 10 & 21633 & - & - \\
\hline 20 & 5233 & - & - \\
\hline 253: 0 & 9133 & 6127 & - \\
\hline 5 & 5940 & 4840 & - \\
\hline 10 & 26207 & 10600 & 530 \\
\hline 20 & - & - & - \\
\hline 254:0 & 22753 & 9807 & 110 \\
\hline 5 & 20407 & 13727 & 380 \\
\hline 10 & 13053 & - & 420 \\
\hline 20 & 6067 & - & - \\
\hline 255: 0 & 14.520 & - & - \\
\hline 5 & 17347 & 4047 & - \\
\hline 10 & - & - & 70 \\
\hline 256: 0 & 6027 & 6973 & - \\
\hline 5 & - & - & - \\
\hline 10 & 16647 & 26347 & 610 \\
\hline 20 & 1067 & - & - \\
\hline 257: 0 & 10667 & 6680 & 670 \\
\hline 5 & 16113 & 20180 & 1040 \\
\hline 10 & 11953 & - & 230 \\
\hline 20 & 4467 & - & 140 \\
\hline 258: 0 & 3207 & - & - \\
\hline 5 & 4353 & 4067 & 490 \\
\hline 10 & 4733 & 1607 & 420 \\
\hline 20 & - & - & 140 \\
\hline 259: 0 & 26367 & 9500 & - \\
\hline 5 & 15300 & 3553 & 120 \\
\hline 10 & 5933 & 3940 & 140 \\
\hline
\end{tabular}


Appendix 4. Values of Clusters A, B and C (cells $I^{-1}$ ) in the Ría de Muros

\begin{tabular}{|c|c|c|c|}
\hline \multirow[t]{2}{*}{ Stn: Depth $(\mathrm{m})$} & \multicolumn{3}{|c|}{ Clusters } \\
\hline & $\mathrm{A}$ & $\mathrm{B}$ & C \\
\hline 301: 0 & - & 1973 & - \\
\hline 5 & 3960 & 7293 & 1240 \\
\hline 10 & - & 14353 & - \\
\hline 302: 0 & 2627 & 3527 & 130 \\
\hline 5 & - & 4353 & 1180 \\
\hline 10 & - & 5520 & - \\
\hline 20 & - & - & - \\
\hline 303: 0 & - & - & 1070 \\
\hline 5 & 1140 & 2927 & 775 \\
\hline 10 & - & 4040 & 855 \\
\hline 20 & - & - & - \\
\hline 304: 0 & - & - & - \\
\hline 5 & 4507 & 8273 & 1070 \\
\hline 10 & 4073 & 21820 & 6255 \\
\hline 20 & - & - & - \\
\hline & - & & \\
\hline 305: 0 & - & 2280 & 200 \\
\hline 5 & - & 5887 & 950 \\
\hline 10 & - & 3067 & 520 \\
\hline 20 & 2533 & 11327 & 1150 \\
\hline 331. 0 & - & - & - \\
\hline 5 & - & 2500 & 395 \\
\hline 10 & - & - & - \\
\hline 20 & - & - & - \\
\hline
\end{tabular}

Figueiras, F. G., Niell, F. X. (1987a). Distribución estacional y espacial del fitoplancton en la ría de Pontevedra (NO de España). Investigación pesq. 51: 293-320

Figueiras, F. G., Niell, F. X. (1987b). Composición del fitoplancton en la ría de Pontevedra (NO de España). Investigación pesq. 51: 371-409

Figueiras, F. G., Niell, F. X., Zapata, M. (1985). Hidrografía de la ría de Pontevedra (NO de España) con mención especial al banco de Placeres. Investigación pesq. 49: 451-472

Figueiras, F. G., Pazos, Y (1991). Hydrography and phytoplankton of the Ría de Vigo before and during a red tide of Gymnodinium catenatum Graham. J. Plankton Res. 13: 589-608

Fraga, F., Figueiras, F. G., Prego, R., Pérez, F. F., Ríos, A. F. (1987). Campana 'Galicia IX'. Oceanica. Datos Informativos Inst. Invest. mar. 20: 1-148

Fraga, F., Margalef, R. (1979\}. Las rías gallegas. In: Estudio y Explotación del mar en Galicia. Secretariado de Publicaciones, Santiago de Compostela, Spain, p. 101-121

Fraga, F., Prego, R. (1989). Condiciones hidrográficas previas a la purga de mar. Cuad. Área Ciencias mar. 4: 21-44

Fraga, S. (1989). Las purgas de mar en las Rías Bajas gallegas. Cuad. Área Ciencias mar. 4: 95-109

Furuya, K., Marumo, R. (1983). The structure of the phytoplankton community in the subsurtace chlorophyll maxima in the western North Pacific Ocean. J. Plankton Res. 5 $393-406$

Gaines, G., Elbrächter, M (1987). Heterotrophic nutrition. In Taylor, F J. R. (ed.) The biology of dinoflagellates. Blackwell Scientific, Oxford, p. 224-268

Gaines, G., Taylor, F. J. R. (1984). Extracellular digestion in marine dinoflagellates. J. Plankton Res. 6: 1057-1061
Hansen, H. P., Grasshoff, K. (1983). Automated chemical analysis. In: Grasshoff, K., Ehrhardt, M. Kremling, K (eds) Methods of seawater analysis, Verlag Chemie, Weinheim, p. 347-379

Kiefer, D. A., Olson, R. J., Holm-Hansen, O. (1976). Another look at the nitrite and chlorophyll maxima in the central North Pacific. Deep Sea Res. 23: 1199-1208

Laval-Peuto, M., Rassoulzadegan, F. (1988). Autofluorescence of marine planktonic Oligotrichina and other ciliates. Hydrobiologia 159: 99-110

Laval-Peuto, M., Salvano, P., Gayol, P., Greuet, C. (1986). Mixotrophy in marine planktonic ciliates: ultrastructural study of Tontonia appendiculariformis (Ciliophora, Oligotrichida). Mar. microb. Fd Webs 1: 81-104

Legendre, L., Legendre, P. (1983). Numerical ecology Elsevier, Amsterdam

Lessard, E. J., Swift, E. (1986). Dinoflagellates from the North Atlantic classified as phototrophic or heterotrophic epifluorescence microscopy. J. Plankton Res. 8: 1209-1215

Margalef, R. (1956). Estructura y dinámica de la purga de mar en la Ría de Vigo. Investigatión pesq. 5: 1.13-134

Margalef, R. (1958). Temporal succession and spatial heterogeneity in phytoplankton. In: Buzzati-Traverso, A. A. (ed.) Perspectives in marine biology. Univ. of California Press, Berkeley, p. 323-349

Margalef, R. (1978). Life-forms of phytoplankton as survival alternatives in an unstable environment. Oceanol. Acta 1 493-509

Margalef, R., Durán, M., Sảiz, F. (1955). El fitoplancton de la Ría de Vigo de enero de 1953 a marzo de 1954. Investigación pesq. 2: 85-129

Margalef, R., Estrada, M., Blasco, D. (1979). Functional morphology of organisms involved in red tides, as adapted to decaying turbulence. In: Taylor, D. L., Seliger, H. H. (eds.) Toxic dinoflagellate blooms. Elsevier/North Holland, New York, p. 89-94

Mouriño, C., Fraga, F. (1985). Determinación de nitratos en agua de mar. Investigación pesq. 49: 81-96

Mouriño, C., Pérez, F. F., Rios, A. F., Manriquez, M., Estrada M., Marrasé, C., Prego, R., Fraga, F. (1985). Campaña 'Galicia VIII' Datos básicos. Datos Informativos Inst. Investns pesq. 13: 1-108

Packard, I T., Blasco, D., Barber, R. T (1978). Mesodinium rubrum in the Baja California upwelling system. In: Boje, R., Tomczak, M. (eds.) Upwelling ecosystems. SpringerVerlag, Berlin, p. 73-89

Pérez, F. F., Fraga, F. (1987). The pH measurements in seawater on NBS scale. Mar. Chem. 21: 315-327

Revelante, N., Gilmartin, M. (1973). Some observations on the chlorophyll maximum and primary production in the eastern North Pacific. Int. Revue ges. Hydrobiol. 58: 819-834

Saijo, Y., lizuka, S., Asaoka, O. (1969). Chlorophyll maxima ın Kuroshio and adjacent area. Mar. Biol. 4: 190-196

Stoecker, D. K., Michaels, A. E., Davis, L. H. (1987). Large proportion of marine planktonic ciliates found to contain functional chloroplasts. Nature, Lond. 326: 790-792

Stoecker, D. K., Silver, M. W., Michaels, A. E., Davis, L. H. (1988). Obligate mixotrophy in Laboea strobila, a ciliate which retains chloroplasts. Mar. Biol. 99: 415-423

Stoecker, D. K., Taniguchi, A., Michaels, A. E. (1989). Abundance of autotrophic, mixotrophic, and heterotrophic planktonic ciliates in shelf and slope waters. Mar Ecol. Prog. Ser. 50: 241-254

Strickland, J D. H., Parsons, T R. (1972). A practical handbook of seawater analysis, 2nd edn. Bull. Fish. Res. Bd Can. $167 \cdot 1-310$ 
Taylor, F. J. R. (1982). Symbioses in marine microplankton. Annls Inst. océanogr., Paris (Fâsc. Suppl.) 58: 61-90

UNESCO (1981). Tenth report of the joint panel on oceanographic tables and standards. Tech. Pap. mar. Sci. (UNESCO) 36: $25 \mathrm{pp}$.

Vandevelde, T., Legendre, L., Therriault J. C., Demers, S., Bah, A. (1987). Subsurface chlorophyll maximum and hydrodynamics of the water column. J. mar Res. 45: 377-396

Varela, M., Cabanas, J. M., Campos, M. J., Penas, E., Sánchez, J., Larrañaga, A., Castillejo, F. F., Río, G. D. (1987a). Composición y distribución del fitoplancton en la plataforma de Galicia durante la campaña 'Breogan-684' (junio de 1984). Boln Inst. esp. Oceanogr. 4: 75-94

Varela, M., Campos, M. J., Cabanas, J. M., Castillejo, F. F., Río, G. D. (1987b). Composición y distribución del fito-

This article was submitted to the editor plancton en la plataforma de Galicia duarnte la campaña 'Breogan-984' (septiembre-octubre de 1984). Boln Inst. esp. Oceanogr 4: 95-106

Venrick, E. L. (1988). The vertical distributions of chlorophyll and phytoplankton species in the North Pacific central environment. J. Plankton Res, 10:987-998

Venrick, E. L., McGowan, J. A., Mantyla, A. W. (1973). Deep maxima of photosynthetic chlorophyll in the Pacific Ocean. Fish. Bull. U. S. 71: 41-52

Wooster, W. S., Bakun, A., McLain, D. R. (1976). The seasonal upwelling cycle along the eastern boundary of the North Atlantic. J. mar. Res. 34: 131-141

Yentsch, C. S., Menzel, D. W. (1963). A method for the determination of phytoplankton chlorophyll and phaeophytin by fluorescence. Deep Sea Res. 10: 221-231

Manuscript first received: November 5, 1990 Revised version accepted: July 22, 1991 